\title{
Prediction of the chemical composition of mutton with near infrared reflectance spectroscopy
}

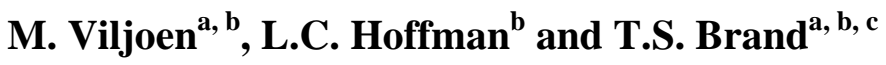 \\ ${ }^{a}$ Elsenburg Agricultural Research Centre, Private Bag X1, Elsenburg 7607, South Africa \\ ${ }^{\mathrm{b}}$ Department of Animal Sciences, University of Stellenbosch, Private Bag X1, Matieland \\ 7602, South Africa \\ ${ }^{\mathrm{C}}$ Department of Anatomy \& Physiology, University of Pretoria, Private Bag X04, \\ Onderstepoort 0110, South Africa
}

\section{Abstract}

Near infrared reflectance spectroscopy (NIRS) was evaluated as a tool to predict the chemical composition of freeze-dried mutton. Samples used for the ash, dry matter (DM), crude protein (CP) and fat calibrations consisted of M. longissimus dorsi (eye muscle) from 19-month-old Merino sheep, while mineral calibrations were developed with $M$. semimembranosus from Merino crossbreed lambs slaughtered at a live weight of $40 \mathrm{~kg}$. Samples were minced, freeze-dried and analysed according to standard laboratory procedures. Samples were scanned (1100-2500 nm) and partial least-squares regression (PLSR) was used to predict the chemical and mineral composition. Multiple correlation coefficients ( $r$ ) and standard error of performance (SEP) for chemical composition constituents were: ash (0.97; 0.15\%), DM (0.96; 0.38\%), CP (1.00; 0.92\%) and fat (1.00; 0.43\%), respectively. K, P, Na, Mg, Fe and Zn showed acceptable SEP values of 600, 900, 77.89, 40, 3.15 and $3.59 \mathrm{mg} / \mathrm{kg}$, respectively. The $r$ values ranged from 0.86 for $\mathrm{Zn}$ and $\mathrm{K}$ to 0.92 for Mg. Very low $r$ values (0.26-0.49) were obtained for $\mathrm{Cu}, \mathrm{B}, \mathrm{Mn}, \mathrm{Ca}$ and Al. It was concluded that NIRS could be used as a rapid tool for predicting proximate chemical composition and certain minerals in freeze-dried mutton. 


\section{Article Outline}

1. Introduction

2. Materials and methods

3. Results and discussion

4. Conclusion

Acknowledgements

References

\section{Introduction}

Near infrared reflectance spectroscopy (NIRS) has been developed as a rapid tool for estimation of chemical composition of foods (Osborne, 1992). It has been used for the determination of moisture and protein content in cereal grains (Reeves, 1994, Shenk and Westerhaus, 1985 and Williams, 1975), moisture, protein and oil contents of oilseeds (Hymowitz et al., 1974 and Krishnan et al., 1994) and major constituents in forages (Norris et al., 1976). This spectropic technique has been developed to replace the laborious, time-consuming and expensive conventional methods, i.e. Kjeldahl method for protein, various solvent extraction methods for fat and oven-drying methods for moisture (Lanza, 1983). Ben-Gera and Norris (1968) used transmission spectroscopy in the NIR range to determine the fat and moisture contents of meat products. Kruggel et al. (1981) estimated fat, moisture and protein contents in fresh emulsified beef and ground lamb by NIR reflectance, while Lanza (1983) determined moisture, protein, fat and calorie contents in raw emulsified pork and beef by NIR reflectance and transmittance. All these studies, however, were conducted on fresh meat. The energy absorbed by water is temperature dependent. This is due to the presence of hydrogen bonds between the molecules, which alter the force constant for the covalent $\mathrm{O} \_\mathrm{H}$ bond and the frequency of the $\mathrm{O} \_\mathrm{H}$ absorption band. The hydrogen bonds may also give a distribution of $\mathrm{O} \_\mathrm{H}$ bond lengths, which give rise to the broad area of absorption (Thyholt and Isaksson, 1997). An increase in temperature causes disruption of hydrogen bonds by thermal collisions, giving a change in the absorption profile. Thus, there will be an increase in absorption at the higher frequency area of the $\mathrm{O} \_\mathrm{H}$ absorption region. A temperature 
shift will also affect hydrophilic components such as protein and carbohydrates, which form hydrogen bonds with the water molecules. Therefore, temperature fluctuations reduce the accuracy of NIR analysis of several compounds if water is present (Thyholt and Isaksson, 1997). Consequently, removing water (e.g. by freeze-drying) means removing the hydrogen bonding interference and giving small molecules, such as sugars, amino acids and minerals, more characteristic spectra.

Minerals do not have reflectance spectra in the infrared region. If some form of correlative relationship can be found, it would be in association with some organic constituent(s) that varies as the mineral varies in the sample (Shenk et al., 1979). Minerals in agricultural products probably exist in both organic and inorganic complexes. The possibility that NIRS could be used for determining mineral concentrations would therefore seem remote (Clark et al., 1987). Clark et al., 1987 and Clark et al., 1989, Shenk et al., 1979 and Shenk et al., 1981 and Valdes et al. (1985) however, reported the use of NIRS for determining mineral composition in forages. Shenk et al. (1979) and Valdes et al. (1985) reported accurate calibrations for K, Mg, Ca and P. Clark et al. (1987) reported successful calibrations for Ca, P, K and Mg and suggested that NIRS is indirectly measuring these minerals by their association with organic acids. They did not, however, find any similarities in wavelengths chosen for $\mathrm{P}$ and those highlighted in phytate or phosphate spectra.

The aim of this study was to develop NIRS calibrations for the proximate and mineral composition of freeze-dried mutton samples.

\section{Materials and methods}

Samples analysed for ash, dry matter (DM), crude protein (CP) and fat used for NIRS calibrations were the same as those used in a study by Cloete (2002) and consisted of $M$. longissimus dorsi from 168 19-month-old Merino sheep. Mineral calibrations were developed with $M$. semimembranosus samples from Merino crossbreed lambs slaughtered at a live weight of $40 \mathrm{~kg}$. The samples were minced, freeze-dried, ground with a Knifetec 1095 Sample Mill (Tecator, Box 70, S-263 21 Hoganäs, Sweden) using a 1 mm sieve and analysed for chemical composition. The protein was measured by a FP-428 Nitrogen and Protein Determinator (Leco Corporation, 3000 Lakeview Avenue, St. Joseph, MI 49085- 
2396). Lipid (petroleum ether extraction) was measured according to AOAC (1984) (Method number 7.061). Moisture was determined by drying a sample (ca. $1.0 \mathrm{~g}$ ) at $100{ }^{\circ} \mathrm{C}$ to a constant weight and ash content by placing the sample in a furnace at $500{ }^{\circ} \mathrm{C}$ overnight (AOAC, 1984) (Method numbers 7.003 and 7.009, respectively). Minerals were determined according to Watson (1994). Element concentrations were measured on an ICP-AES (inductive coupled plasma atomic emission spectrophotometer; Liberty Series AA Varian).

All samples were divided into two sets for each constituent: a larger set for the calibration equations (calibration set) and a smaller set for the validation (validation set) of the calibrations ( $n$ values are shown in Table 1, Table 2, Table 4 and Table 5, respectively). Outliers were removed according to suggestions by the software (Bran + Luebbe SESAME Version 2.00-software, BRAN + LUEBBE GmbH, Norderstedt, Germany). Outliers listed as ' $\mathrm{T}$ '- and ' $\mathrm{H}$ '-values were taken into consideration. The ' $\mathrm{T}$ '-value measures how closely the reference value matches the predicted value. The spectrum is listed and flagged with an asterisk $\left(^{*}\right)$ if the ' $\mathrm{T}^{\prime}$-value is greater than 2.5 times the standard error of calibration. These values can be potential outliers, because they do not fit the calibration equation as well as the other samples. The ' $\mathrm{H}$ '-value is a measure of leverage. It puts a numerical value on the influence of a particular spectrum in determining the regression line. It is a measure of multidimensional distance of a spectrum to the regression line. If a spectrum with a large ' $\mathrm{H}$ '-value has a small ' $\mathrm{T}$ 'value, it is likely to be valuable for the calibration. If both the ' $\mathrm{H}$ '- and the ' $\mathrm{T}$ '-values are large, it is more likely to be a true outlier. Equations of best fit were chosen for each constituent based on statistical analysis. After removal of the outliers, every fifth sample was selected for the validation sets. Wet chemistry and NIRS analyses were done simultaneously for all the samples.

\section{Table 1.}

Summary of chemical composition (\%) of freeze-dried mutton samples used in the calibration set, showing number of samples $(n)$, mean, range of values, standard deviation (S.D.) and coefficient of variation (C.V.) 


\begin{tabular}{|l|l|l|l|l|l|l|}
\hline Chemical component (\%) & $n$ & Mean & Min & Max & S.D. & C.V. \\
\hline Ash & 128 & 3.81 & 2.09 & 5.17 & 0.70 & 18.37 \\
\hline DM & 131 & 93.41 & 90.55 & 95.92 & 1.07 & 1.15 \\
\hline CP & 118 & 73.92 & 52.94 & 86.95 & 8.97 & 12.13 \\
\hline Fat & 120 & 19.20 & 7.30 & 51.80 & 11.02 & 57.40 \\
\hline
\end{tabular}

Table 2.

Summary of chemical composition (\%) of freeze-dried mutton used in the validation set, showing number of samples ( $n$ ), mean, range of values, standard deviation (S.D.) and coefficient of variation (C.V.)

\begin{tabular}{|l|l|l|l|l|l|l|}
\hline Chemical component (\%) & $\boldsymbol{n}$ & Mean & Min & Max & S.D. & C.V. \\
\hline Ash & 26 & 3.87 & 2.27 & 4.67 & 0.68 & 17.57 \\
\hline DM & 26 & 93.45 & 90.55 & 95.92 & 1.29 & 1.38 \\
\hline CP & 23 & 71.74 & 53.49 & 84.33 & 10.48 & 14.61 \\
\hline Fat & 27 & 19.76 & 7.30 & 51.80 & 12.24 & 61.94 \\
\hline
\end{tabular}

NIRS analyses were done with an InfraAlyzer 500 near infrared reflectance analyser (IA500) using Bran + Luebbe SESAME Version 2.00-software (BRAN + LUEBBE GmbH). Approximately $6 \mathrm{~g}$ of each sample was packed into an open sample cup. Spectra were measured over the wavelength range $1100-2500 \mathrm{~nm}$, recorded as $\log 1 / R$ at $2 \mathrm{~nm}$ intervals. Calibration equations were developed for each constituent following the recommended protocol of Windham et al. (1989). Calibrations were developed by means of partial least-squares regression (PLSR) on normalised spectra for $\mathrm{Na}, \mathrm{Fe}, \mathrm{Zn}$ and $\mathrm{Mn}$, on first derivative spectra (segment $=1$; gap $=0$ ) for $\mathrm{Al}, \mathrm{Cu}, \mathrm{Mg}$ and $\mathrm{P}$, and on second derivative spectra (segment $=1$; gap $=0$ ) for ash, DM, CP, fat, B, Ca and K content. 


\section{Results and discussion}

The range, mean values, standard deviations (S.D.) and coefficients of variation (C.V.) of the calibration and validation sets for the chemical composition constituents are shown in Table 1 and Table 2, respectively. The variation in the chemical composition of the samples used seemed to cover the whole spectrum found for mutton reported in the literature for mutton (Berg et al., 1997, Hopkins et al., 1992 and Teixeira et al., 1996). The fat content of the mutton (Table 1) showed a large variation (7.30-51.80\%). Kruggel et al. (1981) suggested, in a study on ground lamb meat, that NIRS is not as suitable for the determination of protein compared to the determination of fat and moisture when used with lamb meat samples containing 17.8-26.2\% fat. The study (Kruggel et al., 1981), however, was conducted on raw meat and it was found that the fat content influenced the particle size of the samples. This phenomenon was not observed in this investigation, possibly due to the use of freeze-dried samples.

Table 3 shows the statistics, including standard errors of calibration (SEC) and multiple correlation coefficient $(r)$ values for the equations of best fit obtained for each of the constituents. The $r$ values for the validation sets and standard errors of performance (SEP) are also shown in Table 3, as well as the standard error of laboratory (SEL) (Snedecor and Cochran, 1980) and predicted mean values. If the SEP for the validation is within two multiplications of the SEL for the primary reference method analysis, the final NIRS equation can be accepted for use, and the SEP for validation can be used as a reliable indication of the accuracy of the final NIRS equation (Windham et al., 1989). All four of the chemical constituent calibrations fitted these limitations and could be accepted for rapid predictions of the constituents (ash $=0.15 \%$ (SEP) veraus $0.13 \%$ (SEL); $\mathrm{DM}=0.38 \%(\mathrm{SEP})$ versus $0.25 \%(\mathrm{SEL}) ; \mathrm{CP}=0.92 \%(\mathrm{SEP})$ versus $2.18 \%(\mathrm{SEL})$; fat $=0.43 \%(\mathrm{SEP})$ versus $2.36 \%(\mathrm{SEL}))$. The SEC and $r$ values for CP $(1.42 \%$ and 0.99$)$ and fat $(0.66 \%$ and 1.00$)$ were similar to that reported by Kruggel et al. (1981) who noted values of $0.61 \%$ and 0.77 for protein and $2.41 \%$ and 0.85 for fat in raw lamb. The reason for the difference between values obtained in the two studies could be due to the freezedried state of the samples used in this investigation. The physical appearance of freezedried meat is more homogenous than raw minced meat, due to the influence of the fat on the particle size of raw minced meat samples (Kruggel et al., 1981). Water is extracted 
and cannot have any influence on possible temperature fluctuations. The SEP values from this investigation were similar to values obtained in studies with wet beef (DM $=0.59 \%$; $\mathrm{CP}=1.15 \%$; fat $=0.27 \%$-Lanza, 1983$) ;(\mathrm{DM}=1.21 \% ; \mathrm{CP}=0.45 \%$; fat $=1.30 \%$ Tøgersen et al., 1999) and wet pork (DM =0.66\%; $\mathrm{CP}=0.92 \%$; fat $=0.28 \%$-Lanza, 1983); $(\mathrm{DM}=1.18 \%$; CP = 0.57\%; fat = 1.35\%—-Tøgersen et al., 1999).

Table 3.

Statistics of the calibration equations of best fit and validation including the number of PLSR factors used for each equation, standard error of calibration (SEC), standard error of performance (SEP) and standard error of laboratory (SEL)

\begin{tabular}{|c|c|c|c|c|c|c|c|c|}
\hline \multirow[t]{2}{*}{$\begin{array}{l}\text { Chemical } \\
\text { component }\end{array}$} & \multirow{2}{*}{$\begin{array}{l}\text { Number } \\
\text { of PLSR } \\
\text { factors }\end{array}$} & \multicolumn{2}{|c|}{$\begin{array}{l}\text { Calibration } \\
\text { set }\end{array}$} & \multicolumn{3}{|c|}{ Validation set } & \multirow{2}{*}{$\begin{array}{l}\text { Laboratory } \\
\text { mean } \\
\text { values (\%) }\end{array}$} & \multirow{2}{*}{$\begin{array}{l}\text { Predicted } \\
\text { mean } \\
\text { values } \\
(\%)\end{array}$} \\
\hline & & $r$ & $\begin{array}{l}\text { SEC } \\
(\%)\end{array}$ & $r$ & $\begin{array}{l}\text { SEP } \\
\text { (\%) }\end{array}$ & SEL (\%) & & \\
\hline Ash & 1 & 0.93 & 0.25 & 0.97 & 0.15 & 0.13 & 3.87 & 3.87 \\
\hline DM & 13 & 0.99 & 0.16 & 0.96 & 0.38 & 0.25 & 93.45 & 93.37 \\
\hline CP & 3 & 0.99 & 1.42 & 1.00 & 0.92 & 2.18 & 71.74 & 71.58 \\
\hline Fat & 2 & 1.00 & 0.66 & 1.00 & 0.43 & 2.36 & 19.76 & 19.76 \\
\hline
\end{tabular}

The correlation between the NIRS predicted values and the laboratory determined values for the proximate composition are shown in Fig. 1. 

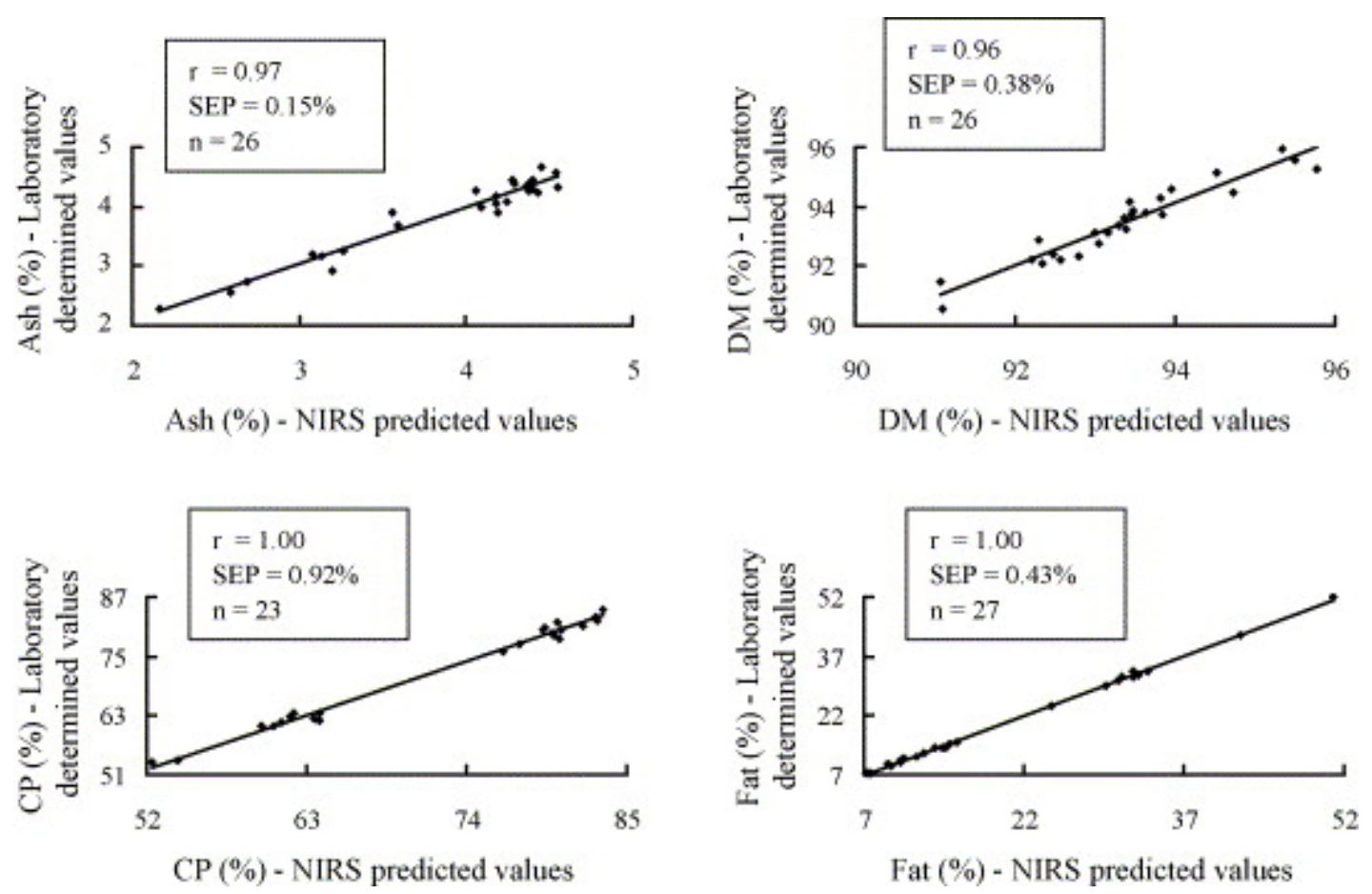

Fig. 1. Relationship between laboratory determined and NIRS predicted values for ash, DM, CP and fat content in freeze-dried mutton, using between 23 and 27 samples for each validation.

Some of the important wavelengths for water (1190; $1940 \mathrm{~nm})$ (Osborne et al., 1993), protein $(1680 ; 2050 ; 2180 \mathrm{~nm})$ (Osborne et al., 1993) and fat (1200; 1734; 1765; 2310; $2345 \mathrm{~nm}$ ) (Osborne et al., 1993) in freeze-dried mutton corresponded with wavelengths noted for the same constituents in freeze-dried ostrich meat (Viljoen et al., 2005), in spite of the differences in protein and fat composition of the different types of meat. The range, mean values, standard deviations and coefficients of variation of the calibration and validation sets for the minerals are shown in Table 4 and Table 5, respectively. The number of samples used for the $\mathrm{K}, \mathrm{Na}, \mathrm{B}$ and $\mathrm{Mn}$ calibrations were less than the minimum number (50) of samples suggested for a narrow-based population (Windham et al., 1989). This was, however, the only samples available and calibrations were attempted to test the accuracy of NIRS for the particular minerals. If the number of samples were to be increased, it would result in more robust, and probably more accurate, calibrations. 
Table 4.

Summary of the mineral composition (mg/kg freeze-dried) of the calibration set for freeze-dried mutton meat showing number of samples $(n)$, mean, range of values, standard deviation (S.D.) and coefficient of variation (C.V.)

\begin{tabular}{|l|l|l|l|l|l|l|}
\hline Mineral & $\boldsymbol{n}$ & Mean & Min & Max & S.D. & C.V. \\
\hline $\mathrm{K}$ & 49 & 9100.00 & 7400.00 & 11500.00 & 1100.00 & 12.08 \\
\hline $\mathrm{P}$ & 51 & 8200.00 & 5000.00 & 10600.00 & 1900.00 & 23.17 \\
\hline $\mathrm{Na}$ & 48 & 1154.67 & 831.00 & 1629.00 & 173.45 & 15.02 \\
\hline $\mathrm{Mg}$ & 52 & 600.00 & 500.00 & 700.00 & 60.00 & 10.00 \\
\hline $\mathrm{Cu}$ & 52 & 0.79 & 0.57 & 2.09 & 0.21 & 26.58 \\
\hline $\mathrm{Fe}$ & 52 & 35.89 & 26.20 & 58.40 & 6.60 & 18.39 \\
\hline $\mathrm{Zn}$ & 50 & 56.78 & 45.90 & 72.30 & 6.07 & 10.69 \\
\hline $\mathrm{B}$ & 44 & 0.46 & 0.24 & 0.90 & 0.15 & 32.61 \\
\hline $\mathrm{Mn}$ & 40 & 0.31 & 0.24 & 0.46 & 0.05 & 16.13 \\
\hline $\mathrm{Ca}$ & 51 & 200.00 & 100.00 & 300.00 & 60.00 & 30.00 \\
\hline $\mathrm{Al}$ & 51 & 4.62 & 2.72 & 8.31 & 1.41 & 30.52 \\
\hline
\end{tabular}

Table 5.

Summary of the mineral composition (mg/kg freeze-dried) of the validation set for freeze-dried lamb meat showing number of samples $(n)$, mean, range of values, standard deviation (S.D.) and coefficient of variation (C.V.) 


\begin{tabular}{|l|l|l|l|l|l|l|}
\hline Mineral & $n$ & Mean & Min & Max & S.D. & C.V. \\
\hline $\mathrm{K}$ & 10 & 9300.00 & 8300.00 & 11500.00 & 1200.00 & 12.90 \\
\hline $\mathrm{P}$ & 10 & 8800.00 & 5400.00 & 10400.00 & 1500.00 & 17.05 \\
\hline $\mathrm{Na}$ & 10 & 1170.00 & 960.00 & 1629.00 & 179.44 & 15.34 \\
\hline $\mathrm{Mg}$ & 11 & 600.00 & 500.00 & 700.00 & 80.00 & 13.33 \\
\hline $\mathrm{Cu}$ & 10 & 0.75 & 0.58 & 0.94 & 0.12 & 16.00 \\
\hline $\mathrm{Fe}$ & 10 & 35.12 & 26.20 & 47.90 & 6.73 & 19.16 \\
\hline $\mathrm{Zn}$ & 10 & 58.93 & 51.50 & 72.30 & 7.05 & 11.96 \\
\hline $\mathrm{B}$ & 10 & 0.45 & 0.30 & 0.67 & 0.14 & 31.11 \\
\hline $\mathrm{Mn}$ & 10 & 0.30 & 0.24 & 0.37 & 0.04 & 13.33 \\
\hline $\mathrm{Ca}$ & 10 & 200.00 & 100.00 & 300.00 & 60.00 & 30.00 \\
\hline $\mathrm{Al}$ & 10 & 4.47 & 3.60 & 6.10 & 0.89 & 19.91 \\
\hline
\end{tabular}

Table 6 shows the SEC and $r$ values for the equations of best fit obtained for each of the constituents. The $r$ values for the validation sets and SEP values are also shown in Table 6 , as well as the SEL and predicted and laboratory mean values. Calibrations which were acceptable on account of their SEP values in comparison with the SEL values were: $\mathrm{K}$ (600 mg/kg versus $400 \mathrm{mg} / \mathrm{kg}$ ); P (900 mg/kg versus $500 \mathrm{mg} / \mathrm{kg}$ ); $\mathrm{Na}$ (77.89 mg/kg versus $56.75 \mathrm{mg} / \mathrm{kg}$ ), $\mathrm{Mg}$ (40 mg/kg versus $20 \mathrm{mg} / \mathrm{kg}$ ); Fe (3.15 mg/kg versus $2.13 \mathrm{mg} / \mathrm{kg}$ ) and $\mathrm{Zn}$ (3.59 mg/kg versus $2.23 \mathrm{mg} / \mathrm{kg}$ ). Clark et al. (1987) suggested that NIRS is indirectly measuring these minerals by their association with organic constituents(s) that varies as the mineral varies in the sample. 
Table 6.

Statistics of the calibration equations of best fit and validation including the number of PLSR factors used for each equation, standard error of calibration (SEC), standard error of performance (SEP) and standard error of laboratory (SEL)

\begin{tabular}{|c|c|c|c|c|c|c|c|c|}
\hline \multirow[t]{2}{*}{$\begin{array}{l}\text { Chemical } \\
\text { Component }\end{array}$} & \multirow{2}{*}{$\begin{array}{l}\text { Number } \\
\text { of PLSR } \\
\text { factors }\end{array}$} & \multicolumn{2}{|c|}{$\begin{array}{l}\text { Calibration } \\
\text { set }\end{array}$} & \multicolumn{3}{|c|}{ Validation set } & \multirow{2}{*}{$\begin{array}{l}\text { Labora- } \\
\text { tory } \\
\text { mean } \\
\text { values } \\
\text { (mg/kg) }\end{array}$} & \multirow{2}{*}{$\begin{array}{l}\text { Predic- } \\
\text { ted } \\
\text { mean } \\
\text { values } \\
\text { (mg/kg) }\end{array}$} \\
\hline & & $r$ & $\begin{array}{l}\text { SEC } \\
(\mathrm{mg} / \mathrm{kg})\end{array}$ & $r$ & $\begin{array}{l}\text { SEP } \\
(\mathrm{mg} / \mathrm{kg})\end{array}$ & $\begin{array}{l}\text { SEL } \\
\text { (mg/kg) }\end{array}$ & & \\
\hline K & 5 & 0.94 & 400.00 & 0.86 & 600.00 & 400.00 & 9300.00 & 9400.00 \\
\hline $\mathrm{P}$ & 5 & 0.85 & 1100.00 & 0.88 & 900.00 & 500.00 & 8800.00 & 8500.00 \\
\hline $\mathrm{Na}$ & 5 & 0.84 & 100.17 & 0.89 & 77.89 & 56.75 & 1170.00 & 1153.63 \\
\hline Mg & 5 & 0.82 & 40.00 & 0.92 & 40.00 & 20.00 & 600.00 & 600.00 \\
\hline $\mathrm{Cu}$ & 5 & 0.73 & 0.15 & 0.47 & 0.14 & 0.04 & 0.75 & 0.80 \\
\hline $\mathrm{Fe}$ & 2 & 0.70 & 4.80 & 0.88 & 3.15 & 2.13 & 35.12 & 35.86 \\
\hline Zn & 3 & 0.67 & 4.68 & 0.86 & 3.59 & 2.23 & 58.93 & 57.83 \\
\hline B & 3 & 0.60 & 0.13 & 0.39 & 0.12 & 0.04 & 0.45 & 0.44 \\
\hline $\mathrm{Mn}$ & 4 & 0.59 & 0.04 & 0.29 & 0.04 & 0.01 & 0.30 & 0.30 \\
\hline $\mathrm{Ca}$ & 3 & 0.58 & 50.00 & 0.49 & 50.00 & 20.00 & 180.00 & 190.00 \\
\hline $\mathrm{Al}$ & 1 & 0.32 & 1.35 & 0.26 & 0.86 & 0.28 & 4.47 & 4.58 \\
\hline
\end{tabular}

The relative small numbers of samples, which were randomly selected for validation, could result in samples deviating a lot form the mean of the selected samples. In the validation set for $\mathrm{Na}$, most of the samples ranged between 960 and $1237 \mathrm{mg} / \mathrm{kg}$, except 
for one sample with the concentration of $1629 \mathrm{mg} / \mathrm{kg}$. It is conceded that the leverage caused by this particular data point could influence the outcome of the validation, but at present this is the only samples available. An increase in the number of samples for both the calibration and validation sets would probably solve this problem. Further research is necessary to conclude to the accuracy of NIRS for prediction of minerals in freeze-dried mutton.

The correlation between the NIRS predicted values and the laboratory determined values for the mineral composition are shown in Fig. 2, Fig. 3 and Fig. 4.
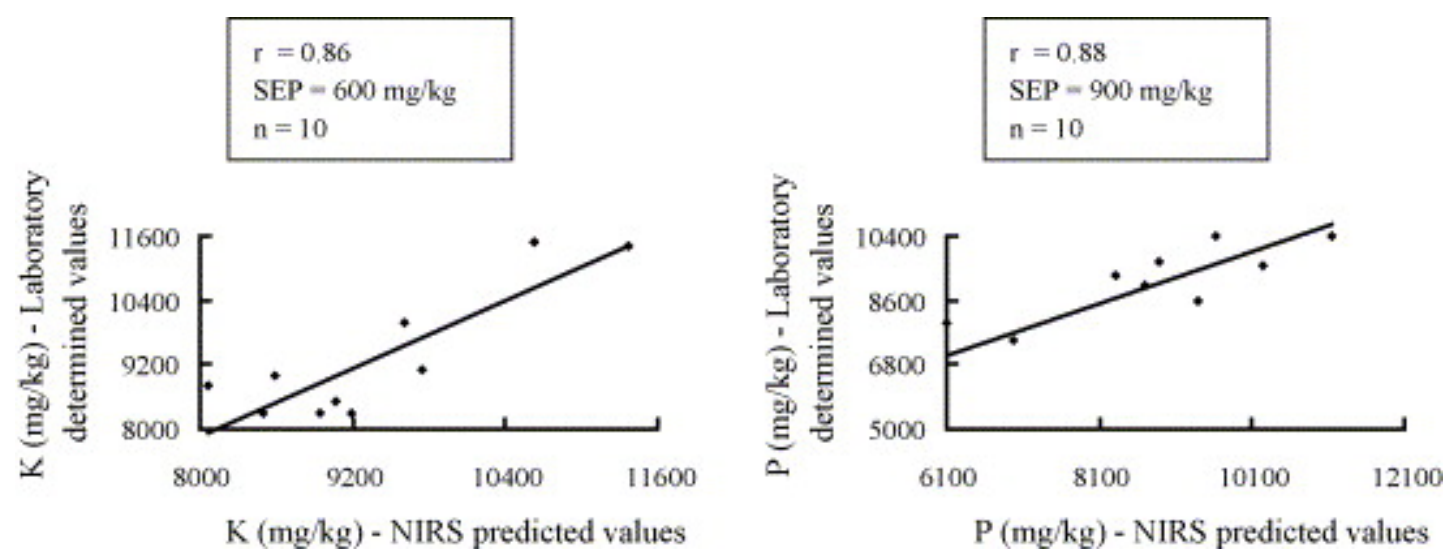

Fig. 2. Relationship between laboratory determined and NIRS predicted values for K and $\mathrm{P}$ in freeze-dried mutton, using 10 samples for each validation. 

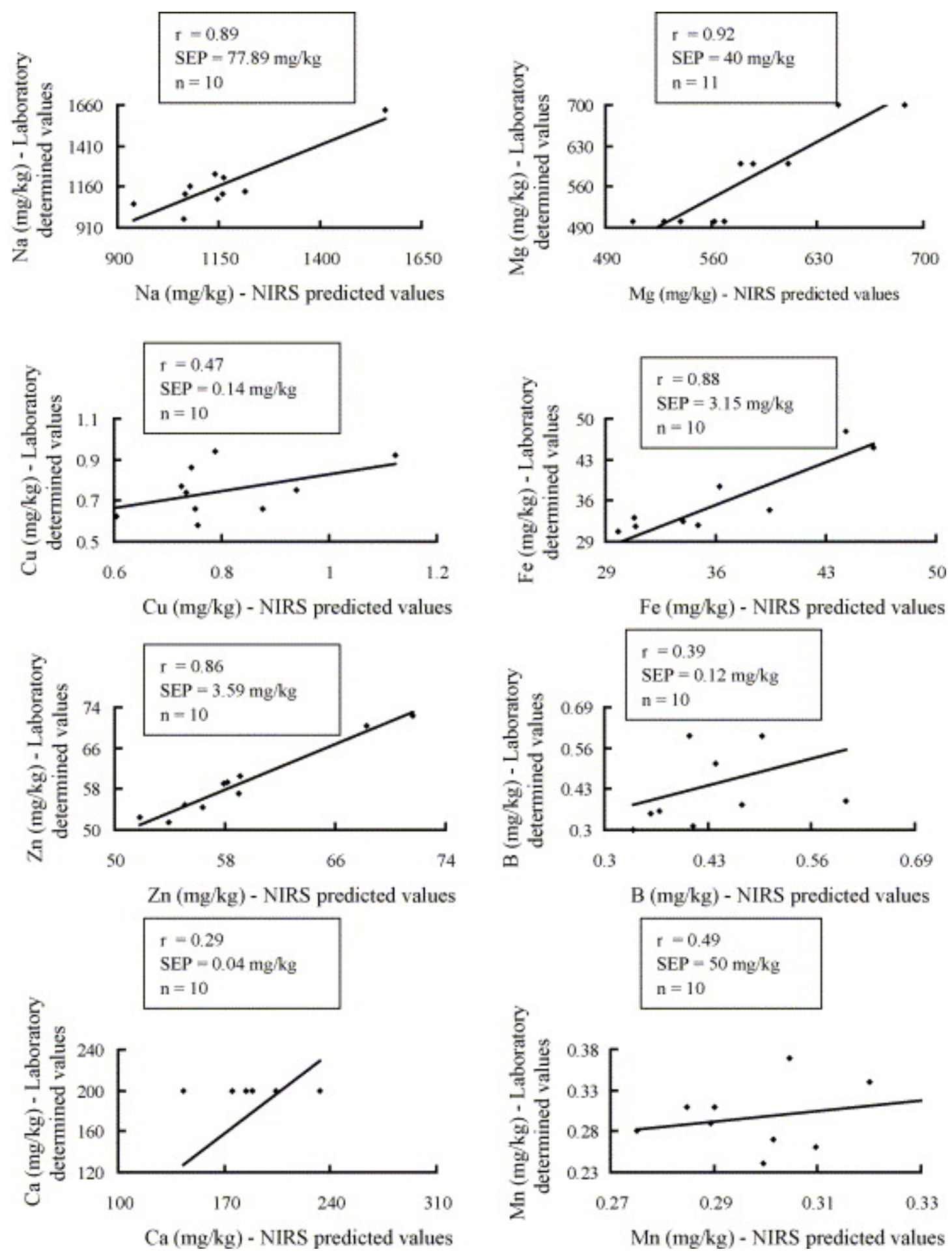

Fig. 3. Relationship between laboratory determined and NIRS predicted values for $\mathrm{Na}$, $\mathrm{Mg}, \mathrm{Cu}, \mathrm{Fe}, \mathrm{Zn}, \mathrm{B}, \mathrm{Ca}$ and $\mathrm{Mn}$ in freeze-dried mutton, using 10 or 11 samples for each validation. 


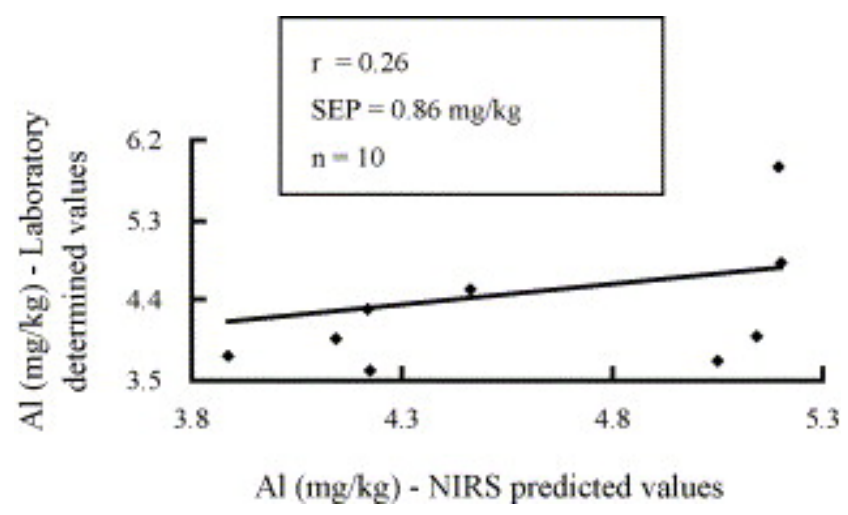

Fig. 4. Relationship between laboratory determined and NIRS predicted values for $\mathrm{Al}$ in freeze-dried mutton, using 10 samples for the validation.

\section{Conclusion}

The major advantage of near infrared reflectance spectroscopy analysis is that once the instrument is calibrated, the results for protein and fat for freeze-dried mutton can be obtained within seconds. Freeze-dried samples led to more accurate calibrations than that noted in the literature, possibly due to the homogenous nature of the samples and the lack of moisture. The latter may change the chemical composition of the sample with fluctuations in temperature. Freeze-drying, however, can be expensive and timely. This led to the conclusion that if NIRS is to be used in the industry for quality control purposes, it would probably be more cost effective to have a less accurate calibration using raw meat than a more accurate calibration using freeze-dried meat. Accurate use of NIRS to determine mineral composition in mutton appears limited to certain minerals (K, P, Na, Mg, Fe and Zn) only.

\section{References}

AOAC, 1984 AOAC, Official Methods of Analysis (14th ed.), Association of Official Analytical Chemists, Inc., Arlington, Virginia, USA (1984) pp. 152-169.

Ben-Gera and Norris, 1968 I. Ben-Gera and K.H. Norris, Direct spectrophotometric determination of fat and moisture in meat products, J. Food Sci. 33 (1968), pp. 64-67. 
Berg et al., 1997 E.P. Berg, M.K. Neary, J.C. Forrest and D.L. Thomas, Evaluation of electronic technology to assess lamb carcass composition, J. Anim. Sci. 75 (1997), pp. 2433-2440.

Clark et al., 1987 D.H. Clark, H.F. Mayland and R.C. Lamb, Mineral analysis of forages with near infrared reflectance spectroscopy, Agron. J. 79 (1987), pp. 485-490.

Clark et al., 1989 D.H. Clark, E.E. Cary and H.F. Mayland, Analysis of trace elements in forages by near infrared reflectance spectroscopy, Agron. J. 81 (1989), pp. 91-95. Cloete, 2002 Cloete, J.J.E., 2002. Carcass traits in relation to genotype in sheep. MSc. Thesis. University of Stellenbosch, pp. 11-15.

Hopkins et al., 1992 D.L. Hopkins, K.D. Gilbert, K.L. Pirlot and A.H.K. Roberts, Elliottdale and crossbred lambs: growth rate, wool production, fat depth, saleable meat yield, carcass composition and muscle content of selected cuts, Aust. J. Agric. Res. 32 (1992), pp. 429-434.

Hymowitz et al., 1974 T. Hymowitz, J.W. Dudley, F.I. Collins and C.M. Brown, Estimation of protein and oil concentration in corn, soybean and oat seed by near infrared light reflectance, Crop Sci. 14 (1974), pp. 713-715.

Krishnan et al., 1994 P.G. Krishnan, W.J. Park, K.D. Kepjart, D.L. Reeves and G.L. Yarrow, Measurement of protein and oil content of oat cultivars using near infrared reflectance spectroscopy, Cereal Foods World 39 (1994), pp. 105-108.

Kruggel et al., 1981 W.G. Kruggel, R.A. Field, M.L. Riley, H.D. Radloff and K.M. Horton, Near infrared reflectance determination of fat, protein and moisture in fresh meat, J. Assoc. Anal. Chem. 64 (1981), pp. 692-696.

Lanza, 1983 E. Lanza, Determination of moisture, protein, fat and calories in raw pork and beef by near infrared spectroscopy, J. Food Sci. 48 (1983), pp. 471-474.

Norris et al., 1976 K.H. Norris, R.F. Barnes, J.E. Moore and J.S. Shenk, Predicting forage quality by infrared reflectance spectroscopy, J. Anim. Sci. 43 (1976), pp. 889-897. Osborne, 1992 B.G. Osborne, NIR analysis of baked products. In: D.A. Burns and E.W. Ciurczak, Editors, Handbook of Near Infrared Analysis (1992), pp. 527-548.

Osborne et al., 1993 B.G. Osborne, T. Fearn and P.H. Hindle, Applications of near infrared spectroscopy in food and beverage analysis. In: D. Browning, Editor, Practical NIR Spectroscopy with Applications in Food and Beverage Analysis, Longman Scientific 
\& Technical/Marcel Dekker, Inc., London/270 Madison Avenue, New York, 10016, USA (1993), pp. 145-159.

Reeves, 1994 J.B. Reeves, Use of near infrared reflectance spectroscopy as a tool for screening treated forages and by-products, J. Dairy Sci. 77 (1994), pp. 1030-1037.

Shenk et al., 1979 J.S. Shenk, M.O. Westerhaus and M.R. Hoover, Analysis of forages by infrared reflectance, J. Dairy Sci. 62 (1979), pp. 807-812.

Shenk et al., 1981 J.S. Shenk, I. Landa, M.R. Hoover and M.O. Westerhaus, Description and evaluation of a near infrared reflectance spectro-computer for forage and grain analysis, Crop Sci. 21 (1981), pp. 355-358.

Shenk and Westerhaus, 1985 J.S. Shenk and M.O. Westerhaus, Accuracy of NIRS instruments to analyse forage and grain, Crop Sci. 25 (1985), pp. 1120-1122.

Snedecor and Cochran, 1980 G.W. Snedecor and W.G. Cochran, Statistical Methods (seventh ed.), Iowa State University Press, Ames, Iowa (1980) p. 593.

Teixeira et al., 1996 A. Teixeira, R. Delfa and T. Treacher, Carcass composition and body fat depots of Galego Bragançano and crossbred lambs by Suffolk and Merino Precoce sire breeds, J. Anim. Sci. 63 (1996), pp. 389-394.

Thyholt and Isaksson, $1997 \mathrm{~K}$. Thyholt and T. Isaksson, Near infrared spectroscopy of dry extracts from high moisture food products on solid support-a review, J. Near Infr. Spec. 5 (1997), pp. 179-193.

Tøgersen et al., 1999 G. Tøgersen, T. Isaksson, B.N. Nilsen, E.A. Bakker and K.I. Hildrum, On-line NIR analysis of fat, water and protein in industrial scale ground meat batches, Meat Sci. 51 (1999), pp. 97-102.

Valdes et al., 1985 E.V. Valdes, L.G. Young, I. McMillan and J.E. Winch, Analysis of hay, haylage and corn silage samples by near infrared reflectance spectroscopy, Can. J. Anim. Sci. 65 (1985), pp. 753-760.

Viljoen et al., 2005 M. Viljoen, L.C. Hoffman and T.S. Brand, Prediction of the chemical composition of freeze dried ostrich meat with near infrared reflectance spectroscopy, Meat Sci. 69 (2005), pp. 255-261.

Watson, 1994 C. Watson, Official and Standardized Methods of Analysis (third ed.), The Royal Society of Chemistry, Cambridge (1994). 
Williams, 1975 P.C. Williams, Application of near infrared reflectance spectroscopy to analysis of cereal grains and oilseeds, Cereal Chem. 52 (1975), pp. 561-576.

Windham et al., 1989 W.R. Windham, D.R. Mertens and F.E. Barton II., 1. Protocol for NIRS calibration: sample selection and equation development and validation. In: G.C.

Marten, J.S. Shenk and F.E. Barton II., Editors, Near Infrared Reflectance Spectroscopy (NIRS): Analysis of Forage Quality, United States Department of Agriculture, Springfield, VA, USA (1989), pp. 96-103.

Corresponding author. Tel.: +27 21 8085225; fax: +27 218085120 . 